\title{
Students Need Entrepreneurship Courses Now More Than Ever
}

Sara Cochran (Indiana University)

KEYWORDS: Entrepreneurship, Higher Education, student entrepreneurs, Student innovators.

EDITOR'S NOTE: This is an updated version of an article that we first published in 2017. The author has updated it because it is especially relevant for the postCovid-19 workforce.

Today's graduating college students are entering a more fundamentally different world than any of their predecessors. Our world greatly changed in just the first quarter of 2020 and will continue to change due to the COVID-19 pandemic. Now more than ever, every student should consider taking an entrepreneurship course before leaving college.

Even before the pandemic, our world had been experiencing change, making things such as "stability, predictability and control elusive if not completely unattainable" (Morris, Kuratko, Cornwall, 2013, p. ix). In order to prosper in this dynamic, threatening and complex world, individuals and organizations must be more entrepreneurial in their thinking and their actions. In a rapidly changing era with immediate access to information, connection and resources, more people than ever have access to an unprecedented number of opportunities. But only those who can extract the highpotential ideas from the chaos will thrive. "The at-risk student is one that is not prepared for this entrepreneurial age" (Morris et al., 2013, p. xi).

Participating in an entrepreneurship program positively affects students' desires to start a business, their perceptions of an entrepreneurial career (Hsu, Shinnar, \& Powell, 2014), and their self-efficacy, or belief in their abilities to start a business (Fayolle, Gailly, and LassasClerc, 2006; Lo, Sun, \& Law, 2012). Entrepreneurship education has been shown to enhance other skills beyond business startup talents -- including communication skills, leadership skills, and business literacy (Duval-Couetil, \& Long, 2014). It also shows students how to adopt an entrepreneurial attitude, which will make them more responsive to rapid changes in the

market and in society. An entrepreneurial mindset will help them see opportunities where others see chaos and confusion (Kuratko, 2020), something many people are experiencing during this pandemic.

What if every college student took a course in entrepreneurship? Let's explore the ways this could help both the student and society in general.

\section{Entrepreneurs Solve Social Problems}

In such a rapidly changing world, "we don't have time for incremental change - we need dramatic change if we are to solve the complex global problems that plague us today" (Crutchfield \& McLeod Grant, 2012, p. 19). An entrepreneurial approach has proven to be successful at approaching social problems: it's no wonder the United Nations Foundation used a Global Entrepreneurs Council to find innovative solutions to global problems (United Nations Foundation, n.d.). The skills learned in an entrepreneurship classroom can be useful even before the student graduates. As an example, organizations such as Indiana University and Techstars organized Covid-19 themed idea-blaze venture accelerators to tap students' solutions to the problems caused by the coronavirus (Techstars, n.d.; Vlahakis, 2020).

\section{More Entrepreneurs=More Jobs}

Entrepreneurs create most new jobs (Guilles, 2019). Need we say more? In fact, government statistics show small businesses created $65 \%$ of net new jobs in the past 17 years (Pofeldt, 2012) and startups create most net new jobs in the United States (Kane, 2010). To create those jobs, we need entrepreneurs to start businesses. Research shows entrepreneurship education increases a graduate's probability of being involved with a startup (Charney \& Lidecap, 2000; Lange, Marram, Jawahar, Yong, \& Bygrave, 2011). So, 
by taking a course in entrepreneurship, students are more likely to launch startups and therefore create more jobs.

\section{Entrepreneurship is Contagious}

People who know entrepreneurs are more likely to start businesses themselves (Kedrosky, 2013). In entrepreneurship courses, students have the opportunity to engage with practicing entrepreneurs who visit their classroom to lecture, serve as the subject of projects, or provide mentorship for the students' business models. These successful entrepreneurs inspire many students to follow their path.

\section{College Graduates Will be More Successful Business Owners}

Today's traditionally aged college students are from Generation Z, or "Zoomers" (Dimlock, 2019). An estimated $41 \%$ of them say they intend to start their own business (Entrepreneur, 2019). Research shows they will be much more successful if they take a course in entrepreneurship (Lange, et al., 2011) and complete college (Guo, Chen, \& Yu, 2020). With the right skills in place, these entrepreneurial-minded students greatly increase the odds that their startups will be successful and create more jobs.

\section{The Time to Start a Business is Now}

The coronavirus pandemic has been deemed a catalyst for entrepreneurship and innovation (Meyer, Pedersen, \& Ritter, 2020; Mudassir, 2020), similar to other previous pandemics and economic recessions. Crisis creates opportunities for innovation (Meyer et al., 2020) and those businesses that do not embrace the changes caused by this pandemic will not survive in a postcoronavirus world (Mudassir, 2020). Counter to conventional wisdom, researchers from the Kauffman Foundation found that more than half of Fortune 500 companies started in a recession or declining economy -- among them WhatsApp, Instagram, and Venmo (Stangler, 2010). Research has shown that nascent entrepreneurs are able to persist during macroeconomic crises (Davidsson \& Gordon, 2016) and recessions are often the best time to start a business (Lazarow, 2020).

\section{Not Just for Business Students}

Entrepreneurship courses are indispensable even for those who are not thinking about starting their own businesses. Entrepreneurship courses teach the critical skill of opportunity recognition (Morris et al., 2013), which has benefits for everybody in every field. In fact, this is considered a core competency of top-notch researchers (Van Wyck, 2016; Universiteit Gent, n.d.). Only those who can recognize new angles, new possibilities, and new ways of looking at things can distinguish themselves from the masses. Taking a course in entrepreneurship will help train the brain to recognize these opportunities, preparing students to be more successful in graduate school and in their subsequent job search (Van Wyck, 2016).

For those graduates going into the workforce, the job market looks grim for another 10 years or so postpandemic (Pinkser, 2020), making it even more imperative for college graduates to stand out among the masses. The National Association of Colleges and Employers has defined a list of competencies for career readiness that includes critical thinking/problem solving, teamwork/collaboration, oral communication skills, leadership, and career management (NACE, n.d.). And -- you guessed it -- entrepreneurship courses teach these very skills (Morris et al., 2013), meaning even those students who want to work for someone else should be taking a course in entrepreneurship to enhance their skills for today's job market.

\section{Chocolate is in Your Future}

Yes, that yummy stuff $41 \%$ of Americans eat every day (Fears, 2012). Six years ago the Hershey Company posted a job for a Senior Manager of Foresight Activation. That may sound like a fancy title, but basically, Hershey was hiring a chocolate futurist: someone with experience converting existing foresight (trends, forecasts and scenarios) into strategic opportunities. Where better to learn about forecasting and strategic opportunities than in an entrepreneurship classroom? Putting the fancy title aside, I believe Hershey was actually saying they wanted an entrepreneur. Other companies have posted similar positions, such as T Mobile's Senior Strategic Foresight Manager (ZipRecruiter, 2020), ConAgra Foods' Associate Innovation Manager (Glassdoor, 2020), or J. Crew's Analytics and Insights Manager (Jobsearcher, 2020).

So if you are a college student, please sign up for an entrepreneurship course. If you are not a college student, please sign up for an entrepreneurship course. Beyond preparing you to work for forward-thinking 
companies, entrepreneurship education will improve your entrepreneurial mindset and opportunity recognition skills, your entrepreneurial self-efficacy and your desire to start a business. Those skills will serve you well whether you go to graduate school, start a business, or pursue a career in another field. Entrepreneurial activity stimulates economic growth, the 21 st century is speculated to be the golden age for entrepreneurship, and the COVID-19 pandemic has made it even more imperative for an entrepreneurial mindset. You won't want to miss out.

\section{References}

Charney, A., \& Lidecap, G. (2000). Impact of entrepreneurship education, Kauffman

Research Series. Kansas City, MO: Ewing Marion Kauffman Foundation.

Crutchfield, L. R., \& McLeod Grant, H. (2012). Forces for good: The six practices of high-

impact non-profits. San Francisco: Jossey-Bass Publishing.

Davidsson, P. \& Gordon, S. R. (2016). Much ado about nothing? The surprising persistence

of nascent entrepreneurs through macroeconomic crisis. Entrepreneurship Theory \& Practice, 40(4), 915-941

Dimlock, M. (2019). Defining generations: Where Millennials end and Generation $Z$ begins.

Pew Research Center. Retrieved from http://www.pewresearch.org

Duval-Couetil, N., \& Long, Z. (2014). Career impacts of entrepreneurship education: How and when students intend to utilize entrepreneurship in their professional lives. Journal of Business and Entrepreneurship, 26(1), 63-87.

Entrepreneur. (2019, January 15). 41 percent of Gen Zers plan to become entrepreneurs (infographic). Entrepreneur. Retrieved from http://www.entrepreneur.com

Fayolle, A., Gailly, B., \& Lassas-Clerc, H. (2006). Assessing the impact of entrepreneurship education programmes: A new methodology. Journal of European
Industrial Training, 30(9), 701-720.

Fears, D. (2012). Americans love their chocolate: How do you stack up? TODAY. Retrieved from http://www.today.com (http://www.today.com/)

Glassdoor. (2020). Associate Innovation Manager. Glassdoor Job Board. Retrieved from http://www.glassdoor.com

Guilles, W. (2019, September 23). Entrepreneurs create most new jobs: Why aren't we talking about them? The Hill. Retrieved from http://www.thehill.com

Guo, Z., Chen, W., \& Yu, A. (2020). Is college education worth it? Evidence from its impacts on entrepreneurship in the United States. Journal of Small Business and Entrepreneurship. Retrieved from http://www.tandfonline.com

Hershey's. (2014). Career opportunities (https://careers.thehersheycompany.com/us/en/)

Senior manager, foresight activation (33870).

HP Careers. (n.d.). Innovation Manager at HP Inc.

Hsu, D. K., Shinnar, R. S., \& Powell, B. C. (2014). Expectancy theory and entrepreneurial motivation: $A$ longitudinal examination of the role of entrepreneurship education. Journal of Business and Entrepreneurship, 26(1), 121-140.

Jobsearcher. (2020). Analytics and Insights Manager. Jobsearcher.com Job Board.

Kane, T. (2010). The importance of startups in job creation and job destruction. Kauffman Foundation Research Series: Firm Formation and Economic Growth. Retrieved from http://www.kauffman.org

Kedrosky, P. (2013). Getting the bug: Is (growth) entrepreneurship contagious? Ewing Marion Kauffman Foundation, October 2013.

Kickul, J., Wilson, F., Marlino, D., \& Barbosa, S. (2008). Are misalignments of perceptions and self-efficacy causing gender gaps in entrepreneurial intentions among our nation's teens. Journal of Small Business and Enterprise Development, 15(2), 321-335.

Kuratko, D. F. (2020). Entrepreneurship: Theory, 
process, practice. Boston, MA: Cengage Publishing.

Lange, J. Marram, E., Jawahar, A., Yong, W., \& Bygrave. W. (2011). Does an entrepreneurship education have lasting value? A study of careers of 4,000 alumni. Frontiers of Entrepreneurship Research 31(6), 210-224.

Lazarow, A. (2020, June 7). Recessions can be the best time to start a business. Bring: The edge of risk.

Lo, C., Sun, H., \& Law, K. (2012). Comparing the entrepreneurial intention between female and male engineering students. Journal of Women's Entrepreneurship and Education, 1-2, 28-51.

Meyer, K., Pedersen, C. L., \& Ritter, T. (2020, April 12). The coronavirus crisis: A catalyst for entrepreneurship. The Conversation. Retrieved from http://www.theconversation.com

Morris, M. H., Kuratko, D. F., \& Cornwall, J. R. (2013). Entrepreneurship programs and the modern University. Northampton, MA: Edward Elgar Publishing, Inc.

Mudassir, H. (2020, March 16). COVID-19 will fuel the next wave of innovation. Entrepreneur. Retrieved from http://www.entrepreneur.com

NACE. (n.d.). Career readiness defined. National Association of Colleges and Employers. Retrieved from http://www.naceweb.org

Pinkser, J. (2020, May 22). The misfortune of graduating in 2020. The Atlantic. Retrieved from http://www.theatlantic.com

Pofeldt, E. (2012). Let's save the economy on our own. Forbes.

Stangler, D. (2009). The economic future just happened. Kauffman Foundation Report. Retrieved from http://www.kauffman.org

Strauss, W., \& Howe, N. (1991). Generations: The history of America's future, 1584-2069. Fort Mill, SC: Quill House Publishers.

Techstars. (n.d.). Techstars Global Online Startup Weekend COVID-19 USA West. Techstars.

United Nations Foundation. (n.d.). Global Entrepreneurs

Council. Retrieved from http://www.unfoundation.org
Universiteit Gent. (n.d.). Courses: Opportunity Recognition. Retrieved from http://www.egent.be Van Wyck, J. M. (2016). Grad students, entrepreneurialism and career preparation. Inside Higher Ed. Retrieved from http://www.insidehighered.com (http://www.insidehighered.com/)

Vlahakis, G. (2020). Faculty at Kelley offer their innovative and entrepreneurial expertise to fighting COVID-19. Kelley School of Business blog.

ZipRecruiter. (2020). Sr Strategic Foresight Manager. ZipRecruiter Job Board. Retrieved from http://www.ziprecruiter.com

Zwilling, M. (2013). A new era for entrepreneurs and startups has begun. Forbes. 